\title{
Tahap Preliminary Research Pengembangan LKPD Berbasis PBL Materi Peluang Kejadian Majemuk
}

\author{
Jamila Wati ${ }^{1}$, Zulfah $^{2)}$ \\ 1,2, Pendidikan Matematika, FIP Universitas Pahlawan Tuanku Tambusai Bangkinang, Riau \\ *jamilawati98@gmail.com
}

\begin{abstract}
Abstrak
Tujuan penelitian ini adalah melakukan analisis tahap awal dalam mengembangkan Lembar Kerja Peserta Didik berbasis Problem Based Learning untuk mengembangkan kemampuan pemecahan masalah matematis secara optimal. Penelitian ini hanya menggunakan tahapan pertama pada model ADDIE . Untuk tahap pertama yaitu tahap analisis. Kegiatan analisis dimulai dengan melakukan analisis kebutuhan, analisis peserta didik, analisis kurikulum, dan analisis konsep. Berdasarkan hasil tahap analisis maka diperoleh kesimpulan bahwa untuk dapat mengasah kemampuan pemecahan masalah matematis peserta didik, guru membutuhkan perangkat pembelajaran yang dapat membantu memfasilitasi peserta didik untuk menumbuh dan mengembangkan kemampuan pemecahan masalah matematisnya pada materi peluang kejadian majemuk. Melalui LKPD yang dilandaskan atau didasarkan atas pendekatan yang telah terbukti untuk memfasilitasi kemampuan pemecahan masalah yaitu Problem Based Learning, maka penggunaan LKPD tersebutdapat membantu peserta didik mengembangkan kemampuan pemecahan masalahnya.
\end{abstract}

Kata kunci: ADDIE; Peluang Kejadian Majemuk; PBL

The purpose of this research is to conduct an initial analysis in developing students worksheets (Lembar Kerja Peserta Didik, LKPD) based on Problem Based Learning (PBL) to develop mathematical problem-solving ability optimally. This research used the first stage on the ADDIE Model, an analysis model. Analysis activity in this research was begun with need analysis, learners' analysis, curriculum analysis, and construct analysis. Based on the result of the analysis stage, it can be concluded that to be able to strengthen students' ability to fix mathematical problems, teachers provide learning resources that will facilitate students to enhance and develop their mathematical problem-solving abilities on multiple occurrence opportunities material. Through the students' worksheet which is based on PBL as a proven approach, the use of students' worksheets can help learners develop their problem-solving ability.

Keywords: ADDIE; Multiple Occurrence Opportunities; PBL

\section{PENDAHULUAN}

Berdasarkan hasil PISA-OECD (Programe for International Student AssessmentOganisation for Economic Cooperation and Development) tahun 2015 menunjukkan bahwa indonesia berada dalam 10 peringkat bawah, dan hasil skor penilaian di bidang matematika menunjukkan angka 386 yang berarti masih di bawah rata-ratanya yaitu 490 (Ponjen \& Suparman, 2019). PISA-OECD merupakan tes yang berfokus pada mata pelajaran sekolah seperti ilmu pengetahuan, membaca dan matematika. Kemahiran peserta didik dalam domain inovatif juga dinilai (pada tahun 2015, domain ini adalah kolaborasi 
pemecahan masalah). Hal ini dapat berarti bahwa kemampuan pemecahan masalah yang menjadi salah satu indikator penilaian, menunjukkan bahwa peserta didik di indonesia masih memiliki kemampuan pemecahan masalah yang rendah.

Kemampuan pemecahan masalah dapat dikatakan sebagai suatu keterampilan dasar atau kecakapan hidup (life skill) yang harus dimiliki, karena setiap manusia harus mampu memecahkan masalahnya sendiri (Husna \& Fatimah, 2013). Menurut Soedjadi (dalam Purnamasari \& Setiawan, 2019) berpendapat bahwa kemampuan pemecahan masalah merupakan suatu keterampilan pada diri peserta didik agar mampu secara matematis memecahkan masalah yang berhubungan dengan matematika atau dalam ilmu lainnya dan masalah yang sering dijumpai peserta didik dikehidupan nyata.

Mengimplementasikan kemampuan pemecahan masalah sebagai tujuan pendidikan sangat dibutuhkan dalam memperoleh pengetahuan yang dapat diterapkan serta membantu peserta didik agar terlatih dalam menghadapi berbagai masalah dalam kehidupan nyata peserta didik.Adapun indikator pemecahan masalah menurut Polya (Mariam, Nurmala, Nurdianti, Rustyani, Desi, \& Hidayat, 2019) terdapat tahap - tahap dalam memecahkan masalah matematis diantaranya yakni; (1) memahami soal atau masalah; (2) membuat rencana atau cara untuk menyelesaikannya; (3)menyelesaikan masalah ; (4) memeriksa kembali hasil yang didapat dan langkah-langkah pengerjaannya.

Hasil observasi dan wawancara yang dilakukan peneliti terhadap guru matematika di sekolah SMA menyebutkan bahwa masih banyak peserta didik memiliki tingkat kemampuan pemecahan masalah matematis yang rendah. Ini terlihat pada saat pengerjaan soal pemecahan masalah, peserta didik tidak menyelesaikan soal yang diberikan dengan benar. Peserta didik tidak mampu mencapai beberapa indikator dari kemampuan pemecahan masalah yang diantaranya tidak mampu melaksanakan strategi penyelesaian dengan baik, serta memeriksa kembali jawaban yang diperoleh.

Permasalahan mengenai rendahnya kemampuan pemecahan masalah peserta didik disebabkan karena pada saat proses pembelajaran, peserta didikhanya mengunakan buku teks yang disediakan oleh sekolah. Buku tersebut belum mampu memfasilitasi peserta didik memiliki kemampuan pemecahan masalah yang bagus, karena masalah yang diberikan dalam buku teks tersebut sulit untuk dipahami oleh peserta didik.

Selanjutnya, Depdiknas (2008) menyebutkan bahwa salah satu kelemahan buku teks jika dilihat dari strukturnya adalah tidak adanya komponen petunjuk belajar, informasi pendukung dan langkah kerja penyelesaian soal kurang jelas, pemakaian buku teks hanya memungkinkan komunikasi satu arah yang berakibat pada kurangnya kesempatan peserta 
didik untuk mengembangkan pola pikir dan pembentukan konsep sehingga peserta didik kesulitan untuk memahami materi yang diajarkan.

Disamping itu, sulitnya masalah yang diberikan membuat peserta didik enggan menyelesaikan masalah yang diberikan. Kurangnya aktivitas dan interaksi dalam proses pembelajaran juga berdampak pada rendahnya kemampuan pemecahan masalah peserta didik. Kemampuan pemecahan masalah yang masih minim bukan sepenuhnya kesalahan dari peserta didik. Salah satu faktornya disebabkan oleh kurang efektifnya bahan ajar yang digunakan dalam menunjang proses pembelajaran (Nurzazili, Irma, \& Rahmi, 2018). Agar terciptaya pembelajaran matematika yang komunikatif, guru perlu mengembangkan kreatifitas untuk merencanakan, menyiapkan, dan membuat bahan ajar yang kaya inovasi sehingga menarik bagi peserta didik.

Salah satu bahan ajar yang dapat digunakan oleh guru dalam proses pembelajaran adalah Lembar Kerja Peserta Didik (LKPD).LKPD merupakan suatu bahan ajar cetak berupa lembar-lembar kertas yang berisi materi, ringkasan, dan petunjuk-petunjuk pelaksanaan tugas pembelajaran yang harus dikerjakan oleh peserta didik, yang mengacu pada kompetensi dasar yang harus dicapai. Peserta didik mendapatkan pengetahuan dan pemahaman terhadap konsep yang dipelajarinya dengan melakukan kegiatan sesuai petunjuk LKPD, bukan dari penjelasan guru (Prastowo,2012).

Hasil wawancara selanjutnya yang diperoleh dari beberapa guru matematika di sekolah menyebutkan bahwa bahan ajar seperti LKPD pernah digunakan, hanya saja tujuan pembelajaran tidak tercapai dengan baik. Hal tersebut terjadi karena LKPD yang tersedia pembuatannya kurang maksimal dan tidak menarik. Padahal di dalam LKPD memuat sekumpulan kegiatan mendasar yang harus dilakukan oleh peserta didik untuk memaksimalkan pemahaman dalam upaya pembentukan kemampuan dasar sesuai indikator pencapaian hasil belajar yang harus ditempuh (Prisiska, Hapizah, \& Yusuf, 2017)

Melalui LKPD peserta didik merasa diberi tanggung jawab untuk menyelesaikan tugas dan merasa harus mengerjakannya terlebih lagi jika guru memberikan perhatian penuh terhadap hasil pekerjaan mereka sehingga peserta didik terlibat aktif dalam pembelajarannya (Pariska, Elniati, \& Syafriandi, 2012). Namun LKPD yang banyak dijumpai di sekolahsekolah hanya berisi ringkasan materi dan kumpulan soal saja, sehingga membuat peserta didik merasa kesulitan dan kebingungan dalam mengerjakannya.

Dalam hal ini perlu adanya suatu inovasi baru terhadap Lembar Kerja Peserta Didik (LKPD) yang dapat menunjang proses pembelajaran dalam pemecaham masalah.Inovasi yang dilakukan pada LKPD tersebut dapat berupa penggunaan suatu model atau strategi 
pembelajaran yang dijadikan sebagai landasan dalam mengembangkan LKPD. LKPD akan semakin optimal jika berlandaskan pada salah satu model atau strategi pembelajaran yang memiliki tujuan untuk meningkatkan kemampuan pemecahan masalah peserta didik dan mengajarkan cara menyelesaikan sebuah permasalahan. Salah satu model/ strategi pembelajaran yang dapat digunakan untuk mencapai tujuan tersebut adalah melalui Problem Based Learning.

Problem Based Learningadalah suatu pendekatan pembelajaran yang menempatkan siswa pada permasalahan yang autentik (nyata) sehingga diharapkan peserta didik dapat menumbuhkembangkan keterampilan tingkat yag lebih tinggi dan inkuiri, menyusun pengetahuannya sendiri dan mengembangkan kemandirian dan kepercayaan dirinya (Trianto, 2007). Hal ini sejalan dengan pendapat Sugiyono (2010) yang menyatakan bahwa Problem Based Learning ditandai oleh siswa yang bekerja berpasangan atau dalam kelompokkelompok kecil untuk mengivestigasi masalah dunia nyata. Pembentukan suatu kelompokkelompok dalam proses belajar diharapkan dapat membantu peserta didik untuk memecahan masalah yang dihadapinya, serta dapat dengan mudah untuk memperoleh pengetahuan dan konsep yang dipelajarinya.

Menurut Riyanto (Sari, Johar, \& Hajidin, 2016) dalam PBL guru sebagai motivasi, pengaju permasalah nyata, dan memberikan bahan ajar serta fasilitas yang diperlukan siswa untuk memecahkan masalah. Selama peserta didik melakukan kegiatan pemecahan masalah, guru berperan sebagai tutor yang akan membantu mereka mendefinisikan apa yang mereka tidak tahu dan apa yang mereka perlu ketahui untuk memahami atau memecahkan masalah (Newbledan dalam Anggiana, 2019).

Berbagai penelitian pengembangan sudah dilakukan sebelumnya, bahwa LKPD berpengaruh terhadap kreativitas peserta didik. Penelitian Pawestri \& Heru (2014) menyatakan bahwa LKPD berpengaruh terhadap kompetensi peserta didik. Selanjutnya Penelitian Astuti \& Sari (2017), menyatakan bahwa LKPD yang dikembangkan efektif terhadap aktivitas dan hasil belajar peserta didik.

Hal tersebut mendasari perlunya solusi atas kesulitan yang dialami peserta didik dalam proses pembelajaran, sehingga perlu dikembangkan LKPD berbasis PBL karena PBL merupakan salah satu model pembelajaran yang dapat digunakan untuk mengembangkan pola pikir peserta didik dan membuat peserta didik menjadi aktif. Sesuai dengan pendapat Nata (2011) pembelajaran pemecahan masalah ini merupakan kelanjutan dari pembelajaran pemahaman, pembelajaran diarahkan pada membantu peserta didik merestrukturisasi situasi yang dihadapinya agar dapat memecahkan masalah. 


\section{METODE}

Pada penelitian ini terfokus hanya pada tahap pertama model ADDIE, yaitu tahap Analisis.Menurut Tegeh (Rahmawati \& Madlazim, 2018) model ADDIE terdiri atas 5 langkah, yakni: Analysis (analisa), Design (desain/ perancangan), Development (pengembangan), Implementation (implementasi/ eksekusi), Evaluation (evaluasi/ umpan balik).

Tahap analisis dilakukan dengan tujuan untuk memperoleh informasi mengenai permasalahan yang terdapat pada dunia pendidikan. Selain itu melalui tahap analisis, peneliti memperoleh gambaran sementara dari produk yang dikembangkan. Pada tahap analisis dilakukan analisis kebutuhan, analisis kurikulum, analisis peserta didik , dan analisis konsep.

Pada tahap analisis kebutuhan peneliti mengumpulkan informasi mengenai permasalahan yang terdapat dalam pembelajaran matematika dengan mengobservasi pelaksanaan kegiatan pembelajaran mewawancarai guru matematika dan peserta didik. Hal ini bertujuan untuk mengetahui gambaran permasalahan yang terdapat dalam pembelajaran matematika dan penyebabnya, pelaksanaan pembelajaran serta penggunaan perangkat pembelajaran. Baik dari aspek tercapai atau tidaknya tujuan pembelajaran yang telah ditetapkan dalam kurikulum, deskripsi kegiatan pembelajaran di kelas, dan ada atau tidaknya bahan ajar yang dapat memfasilitasi pengembangan kemampuan pemecahan masalah matematis peserta didik. Wawancara yang dilakukan berpedoman pada daftar pertanyaan pedoman wawancara. Observasi dilakukan untuk melihat aktivitas peserta didik dan melihat penggunaan perangkat pembelajaran yang digunakan oleh guru untuk menyesuaikan informasi yang diberikan oleh guru dengan keadaan yang sebenarnya.

Pada tahap analisis kurikulum dilakukan telaah terhadap kurikulum yang digunakan yaitu Kurikulum 2013. Analisis tersebut bertujuan untuk mengetahui tujuan, isi materi kelas XII SMA yang akan dikembangkan serta untuk mengetahui kemampuan yang harus dimiliki oleh peserta didik setelah mempelajari materi tersebut. Analisis ini berupa penentuan indikator dari materi, Penjabaran KI, KD dan indikator pencapaian kompetensi menjadi pertimbangan untuk menentukan konsep-konsep yang diperlukan dalam pembelajaranmatematika dan mengukur pencapaian KI dan KD.

Analisis peserta didik dilakukan untuk mengetahui kualitas individual peserta didik yang merupakan telah dari kebutuhan peserta didik dan dapat dijadikan petunjuk dalam perancangan perangkat pembelajaran yang akan dibuat. Hal yang dilakukan adalah melihat kecendrungan belajar, karakteristik peserta didik dalam berpikir, dan keterampilan peserta 
didik dalam belajar serta ketertarikan peserta didik dalam menggunakan LKPD. Kegiatan yang dilakukan pada tahap ini adalah dengan memberikan angket kepada peserta didik.Pada bagian akhir, peneliti memberikan angket kepada peserta didik yang memuat pernyataanpernyataan tentang spesifikasi LKPD yang diharapkan.Analisis ini dijadikan sebagai pertimbangan dalam merancang LKPD berbasis PBL.Sedangkan Analisis konsep bertujuan untuk mengidentifikasi konsep-konsep utama yang diajarkan, merinci dan menyusunnya secara sistematis untuk mencapai indikator-indikator pencapaian kompetensi

Teknik pengumpulan data yang digunakan dalam penelitian ini adalah wawancara dan tes. Wawancara dilakukan dengan guru pada saat tahap analisis. Wawancara dilakukan untuk mendapatkan data tentang karakteristik peserta didik, informasi mengenai materi dan startegi atau metode yang digunakan ketika pembelajaran berlangsung, sertapendapat guru mengenai bahan ajar seperti LKPD yang digunakan. Data-data tersebut akan digunakan dalam mengembangkan LKPD berbasis PBL. Sedangkan Tesadalahsekumpulansoal matematika dengan memperhatikan kemampuan pemecahan masalah peserta didik dalam mengolah soal yang diberikan.Hasilteskemudiandianalisis untukmemperolehdatayangdiharapkan.

\section{HASIL PENELITIAN}

Analisis pendahuluan dilakukan pada peserta didik kelas XII SMA. Hasil dari tahap analisis terbagi menjadi hasil analisis kebutuhan, hasil analisis peserta didik, analisis kurikulum, serta analisis konsep.

\section{Hasil Analisis Kebutuhan}

Untuk mendapatkan data, peneliti mengumpulkan informasi dengan cara mengobservasi pelaksanaan kegiatan pembelajaran, mewawancarai guru matematika kelas XII SMA dan memberikan angket kepada peserta didik mengenai permasalahan yang biasa timbul dalam perangkat pembelajaran matematika sehingga perlu untuk mengembangkannya.

Dari hasil analisis kebutuhan ini peserta didik membutuhkan LKPD yang dapat memfasilitasi mereka untuk berpartisipasi aktif dalam mengkonstruksi pengetahuannya dan meningkatkan keterampilan mereka dalam menyelesaikan permasalahan yang berkaitan dengan dunia nyata. Peserta didik menginginkan LKPD yang menarik, mudah dipahami dan penjelasan materinya terperinci serta permasalahan yang dipakai dalam LKPD terkait persoalan matematika dalam konteks kehidupan sehari-hari.

\section{Analisis Kurikulum}

Pada tahap ini dilakukan telaah terhadap kurikulum 2013 untuk mata pelajaran matematika kelas XII SMA yang terdiri dari materi Dimensi tiga, Statistika, Kaidah 
pencacahan dan Peluang Kejadian Majemuk. Analisis ini menjadi pedoman dalam melakukan pengembangan perangkat pembelajaran berbasis PBL. Analisis untuk Kompetensi dasar materi ini adalah dikembangkannya indikator dengan menggunakan pembelajaran PBL untuk mengorganisasikan materi dan menentukan tujuan pembelajaran yang ingin dicapai pada setiap pertemuan. Semua indikator yang dirancang telah disesuaikan dengan KD dan indikator pemecahan masalah namun tidak lepas dari konten kehidupan nyata.

Hasil penjabaran indikator pembelajaran untuk kompetensi inti pengetahuan pada materi Peluang Kejadian majemuk yang diujicobakan dapat dilihat pada Tabel I.

Tabel 1. Perumusan indikator pencapaian kompetensi

\section{Kompetensi dasar}

3.4 Mendeskripsikan dan menentukan peluang kejadian majemuk (peluang kejadian-kejadian saling lepas, saling bebas, dan kejadian bersyarat) dari suatu percobaan acak.

\section{Indikator pembelajaran}

3.4.1 Memahami konsep peluang kejadian majemuk (peluang kejadian-kejadian saling lepas)

3.4.2 Mengidentifikasi fakta dan mendeskripsikan peluang kejadian majemuk (peluang kejadian-kejadian saling lepas)

3.4.3 Memahami konsep peluang kejadiankejadian saling bebas

3.4.4 Mengidentifikasi fakta dan mendeskripsikan peluang kejadian-kejadian saling bebas

3.4.5 Memahami konsep peluang kejadiankejadian bersyarat

4.4.5 Mengidentifikasi fakta dan mendeskripsikan kejadian-kejadian bersyarat.

4.4 Menyelesaikan masalah yang berkaitan dengan kejadian majemuk (peluang kejadiankejadian saling lepas, saling bebas, dan kejadian bersyarat)
4.4.1 Menentukan peluang kejadian majemuk (peluang kejadian-kejadian saling lepas)

4.4.2 Menentukan peluang kejadian majemuk (peluang kejadian-kejadian saling bebas)

4.4.3 Menentukan peluang kejadian majemuk (peluang kejadian-kejadian bersyarat)

Berdasarkan analisis isi kurikulum pada tabel I. susunan KD dengan indikator sudah sesuai. Karena sebelum melakukan penyelesaian terhadap suatu permasalahan, terlebih dahulu peserta didik diharapkan mampu memahami konsep terkait permasalahan yang diberikan.

\section{Analisis peserta didik}

Dari hasil analisis ini diketahui bahwa peserta didik memiliki kemampuan yang heterogen, sehingga tingkat pengetahuan peserta didik ada yang pengetahuan rendah, pengetahuan sedang, dan pengetahuan tinggi. Saat pembelajaran beberapa peserta didik yang berkemampuan rendah banyak membutuhkan bimbingan langsung dari gurunya. Lebih cendrung pasif dalam diskusi kelompok. Peserta didik berkemampuan sedang dapat menerima penjelasan dari guru dan mereka lebih cenderung bertanya dan berdiskusi dengan teman dari 
pada bertanya kepada guru secara langsung. Sedangkan peserta didik yang berkemampuan tinggi dapat menerima penjelasan guru serta dapat memberikan komentar dengan bahasanya sendiri terkait masalah yang diberikan.

Salah satu analisis terhadap contoh soal pemecahan masalah matematis yang diberikan guru kepada peserta didik dapat dilihat pada Gambar 1.

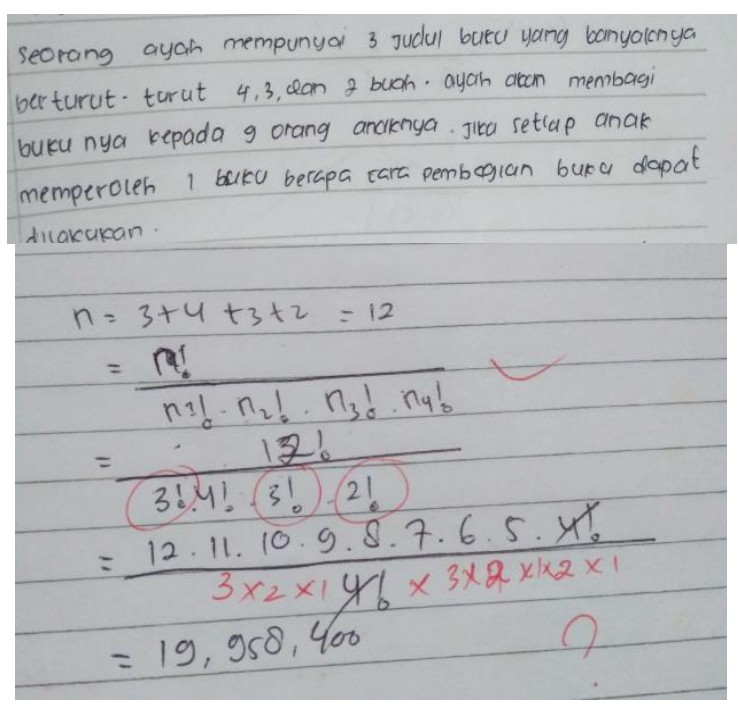

Gambar 1. Jawaban Siswa Menyelesaikan Soal Kemampuan Pemecahan Masalah.

Dalam menyelesaikan suatu permasalahan, peserta didik dari kemampuan tinggi sampai kemampuan rendah rata-rata terlihat masih kebingungan dan kesulitan dalam memahami dan menyelesaikan soal permasalahan yang berbentuk cerita dalam kehidupan nyata yang berkaitan dengan peluang. Sehingga perlu mengembangkan bahan ajar yang dapat memfasilitasi kebiasaan dan mengakomodasi karakter yang dimiliki peserta didik dalam meningkatkan keterampilan dalam menyelesaikan permasalahan sehari-hari yang mereka khususnya kemampuan pemecahan masalah matematis.

\section{PEMBAHASAN}

Berdasarkan karakteristik tersebut, peneliti merasa perlu adanya pengembangan LKPD berbasis PBL. LKPD berbasis Problem Based Learning merupakan LKPD yang dapat membantu peserta didik dalam melakukan pemecahan masalah. Hal ini sejalan dengan kurikulum 2013 yang sedang berlaku saat ini menganjurkan adanya aktivitas aktif siswa dalam proses pembelajaran (Permendikbud, 2013). Implementasi kurikulum 2013 khususnya pada pembelajaran Matematika , siswa dituntut untuk dapat lebih aktif dalam menemukan hal-hal yang baru dan dapat menyelesaikan ataupun menyimpulkan setiap permasalahan yang diberikan. 
Pemilihan PBL ini didasari karena PBL merupakan model pembelajaran yang membantu guru untuk mengaitkan materi dengan situasi nyata peserta didik. Selain itu dengan PBL peserta didik dapat memfasilitasi keberhasilan memecahkan masalah, komunikasi, kerja kelompok, dan keterampilan interpersonal dengan baik (Rusman, 2012). Oleh sebab itu, LKPD berbasis PBL ini merupakan salah satu bahan ajar yang dapat digunakan guru untuk membantu peserta didik menemukan suatu konsep sekaligus meningkatkan kemampuan pemecahan masalah dan aktivitas peserta didik dalam proses pembelajaran.

\section{Analisis konsep}

Analisis konsep bertujuan untuk menentukan isi dan materi pelajaran yang dibutuhkan dalam pengembangan LKPD yang akan dihasilkan, dengan cara mengidentifikasi konsepkonsep utama yang diajarkan, merinci dan menyusunnya secara sistematis sesuai dengan urutan penyajiannya. Materi sangat diperlukan untuk mencapai indikator pencapaian kompetensi. Setelah mengetahui materi yang dipelajari di kelas XII, maka diperlukan analisis konsep. Setelah menganalisis konsep berdasarkan kurikulum yang digunakan ada 4materi pokok yang dipelajari pada kelas XII yaitu Dimensi tiga, Statistika, Kaidah Pencacahan dan Peluang Kejadian Majemuk. Dari hasil Analisis konsep dan karena keterbatasan waktu maka materi yang diujicobakan adalah materi ke 4 yaitu Peluang Kejadian Majemuk. Materi peluang kejadian majemuk memuat permasalahan yang mungkin banyak ditemui peserta didik dalam kehidupan sehari-hari dan peserta didik diharapkan mampu untuk menyelesaikan masalah tersebut.

\section{SIMPULAN}

Berdasarkan uraian hasil dan pembahasan di atas menunjukkan bahwa guru di sekolah membutukan bahan ajar yang dapat memfasilitasi kemampuan pemecahan peserta didik. Dengan adanya inovasi terhadap LKPD akan menjadi penunjang kegiatan proses pembelajaran menjadi lebih optimal. Selain guru, peserta didik juga membutuhkan LKPD yang menarik, mudah dipahami dan penjelasan materinya terperinci serta permasalahan yang dipakai dalam LKPD terkait persoalan matematika dalam konteks kehidupan sehari-hari.

Penggunaan LKPD berbasis PBL dalam proses pembelajaran dapat menambah pemahaman peserta didik tentang materi yang diajarkan. Proses pembelajaran dikelas menjadi lebih bermakna, mereka berpartisipasi aktif dalam mengkonstruksi pengetahuannya dan meningkatkan keterampilan dalam menyelesaikan permasalahan yang berkaitan dengan dunia nyataa sehingga dapat mengembangkan kemampuan pemecahan matematis. 


\section{REFERENSI}

Anggiana, A. D. (2019). Model Problem Based Learning (PBL) untuk Meningkatkan Kemampuan Pemecahan Masalah Matematis Siswa. Pasundan Journal of Research in Mathematics Learning and Education, 4(1), 58-71.

Astuti, \& Sari, N. (2017). Pengembangan Lembar Kerja Siswa (LKS) Pada Mata Pelajaran Matematika Siswa Kelas X SMA. Journal Cendekia, 1(2), 13-24. https://doi.org/https://doi.org/10.31004/cendekia.v1i2.16

Depdiknas. (2008). Panduan Pengembangan Bahan Ajar. Jakarta: Depdiknas.

Kementrian Pendidikan dan Kebudayaan RI. (2013). Peraturan Menteri Pendidikan dan Kebudayaan tentang Standar Proses Pendidikan Dasar dan Menengah. (Permendikbud Nomor 65 tahun 2013). Jakarta, DKI: Penulis. Diakses dari https://bsnp-indonesia.org/wp-content/uploads/2009/06/03.-A.-Salinan-

Permendikbud-No.-65-th-2013-ttg-Standar-Proses.pdf.

Husna, M., \& Fatimah, S. (2013). Peningkatan kemampuan pemecahan masalah dan Komunikasi matematis siswa Sekolah Menengah Pertama melalui model pembelajaran kooperatif tipe Think-pair-share (TPS). Jurnal Peluang, 1(2), 81-92.

Mariam, S., Nurmala, N., Nurdianti, D., Rustyani, N., Desi, A., \& Hidayat, W. (2019). Analisis Kemampuan Pemecahan Masalah Matematis Siswa MTsN Dengan Menggunakan Metode Open Ended Di Bandung Barat. Jurnal Cendekia: Jurnal Pendidikan Matematika, 3(1), 178-186. https://doi.org/10.31004/cendekia.v3i1.94

Nata, A. (2011). Perspektif Islam Tentang Strategi Pembelajaran. Jakarta: Kencana Prenada Media Group

Nurhadi. (2004). Pembelajaran Konstektual dan Penerapannya dalam KBK. Malang: Universitas Negeri Malang.

Nurzazili, N., Irma, A., \& Rahmi, D. (2018). Pengembangan Lembar Kegiatan Siswa (LKS) Berbasis Problem Based Learning (PBL) untuk Memfasilitasi Kemampuan Pemecahan Masalah Matematis Siswa di SMA Negeri 10 Pekanbaru. Jurnal Cendekia: Jurnal Pendidikan Matematika, 2(1), 172-179. https://doi.org/10.31004/cendekia.v2i1.43

Pawestri, E., \& Heru, S. (2017). Pengembangan Perangkat Pembelajaran Lembar Kerja Siswa Dengan Pendekatan Kontekstual Untuk Meningkatkan Kemampuan Pemecahan Masalah Siswa.Jurnal Mercumatika, 2(1), 69-76 
Pariska, I., Elniati, S., \& Syafriandi. (2012). Pengembangan Lembar Kerja Siswa Matematika Berbasis Masalah. Jurnal Pendidikan Matematika, 1(1), 75-80.

Ponjen, D., \& Suparman, S. (2019). Analisis Kebutuhan LKPD Berbasis Problem Based Learning Untuk Meningkatkan Kemampuan Pemecahan Masalah.Prosiding Sendika, 5(1), 185-190.

Purnamasari, I., \& Setiawan, W. (2019). Analisis Kemampuan Pemecahan Masalah Matematis Siswa SMP pada Materi SPLDV Ditinjau dari Kemampuan Awal Matematika. Journal of Medives: Journal of Mathematics Education IKIP Veteran Semarang, 3(2), 207-215. https://doi.org/10.31331/medivesveteran.v3i2.771

Prastowo, A. (2012). Panduan Kreatif Membuat Bahan Ajar Inovatif. Yogjakarta: Diva Press.

Prisiska, R. N., Hapizah, H., \& Yusuf, M. (2017). Pengembangan lks berbasis problem based learning materi aritmetika sosial kelas VII. JPPM (Jurnal Penelitian dan Pembelajaran Matematika), 10(2), 82-94.

Rahmawati, N., K., N. \& Madlazim. (2018). The Development Of Student Workheet Based on Guided Inquiry on "Collision Lab" Virtual Experiment to Improve High School Student Learning Outcomes. Inovasi Pendidikan Fisika, 7(2), 283-286.

Rusman. (2012). Model-Model Pembelajaran Mengembangkan Profesionalisme Guru. Jakarta: Rajawali Pers.

Sari, S.M., Johar, R., \& Hajidin. (2016). Pengembangan Perangkat Problem Based Learning (PBL) dalam Pembelajaran Matematika di SMA. Jurnal Didaktik Matematika, 3(2), $42-53$

Sugiyono. (2010). Metode Penelitian Pendidikan. Bandung : Alfabeta

Trianto. (2007). Model-model Pembelajaran Inovatif Berorientasi Kontruktivistik. Jakarta: Prestasi Pustaka Publisher 